\title{
Debt or Wage-led Growth : the European Integration
}

\author{
Elena Makrevska Disoska \\ University Ss. Cyril and Methodius, Faculty of Economics-Skopje, Skopje, Republic of Macedonia \\ Katerina Toshevska-Trpcevska \\ University Ss. Cyril and Methodius, Faculty of Economics-Skopje, Skopje, Republic of Macedonia
}

\begin{abstract}
This study aims to outline the importance of increasing real wages in European Union member countries. Since the 1970s, the European Union's original member countries (European Union-15) have pursued a neoliberal strategy, favoring exportled growth. This strategy was supposed to increase the European Union's international competitiveness by reducing labor costs and encouraging investment as profits garnered a greater share of national income. Since the 1990s, the European Union's newer members, primarily Central Eastern European countries, have pursued debt-led growth as European Union membership opened financial markets to foreign capital. Both strategies adopted wage moderation and both have been associated with weaker and more volatile growth alongside rising unemployment. We argue that the European Union should adopt a Keynesian demand-led growth model and raise real wages to generate higher effective demand, which is crucial for achieving growth in economies operating below full employment.
\end{abstract}

\footnotetext{
* Corresponding Author: Elena Makrevska Disoska; Ss Cyril and Methodius University in Skopje, Faculty of Economics - Skopje, Blvd. Goce Delcev 9V, 1000 Skopje, Republic of Macedonia; Tel: +3892 328 6847, Fax: +389 2 3118 701, E-mail: elenam@eccf.ukim. edu.mk.

Co-author: Katerina Toshevska-Trpcevska; Ss Cyril and Methodius University in Skopje, Faculty of Economics - Skopje, Blvd. Goce Delcev 9V, 1000 Skopje, Republic of Macedonia; Tel: +3892328 6889, Fax: +38923118 701, E-mail: katerina@eccf.ukim.edu.mk.
} 
JEL Classifications: E12, F15, P51

Keywords: Age-led Growth, Profit Share, Demand, European Union-15, Central and Eastern Europe

\section{Introduction}

The share of wages in national income has declined substantially and globally since the early 1980s (International Monetary Fund 2007, International Labor Organization 2011, Stockhammer 2013). The dramatic decline in developed and developing economies during the post-1980s neoliberal era has accompanied lower economic growth rates globally. This trend is evident among most European countries (International Labor Organization 2011).

Policymakers expected that reducing the share of wages in national incomeand raising the share for profits-would reduce consumption, but they also expected investment and net exports to rise. Exports and imports depend on relative prices, which are functions of unit labor costs, so they reasoned that restraining wages would restrain labor costs and benefit exports. However, the trade-induced effects on economic growth also depend on the degree of openness of the economy and price elasticity of exports and imports (Stockhammer 2015). The world economy is a closed system, and net exports offset each other in closed systems. This outcome is relevant for the European Union (EU). As a large closed economy composed of smaller economies, individual member states can grow via wage restraint but the EU as a whole cannot.

In contrast, increasing the share of wages in national income typically supports demand via consumption and generates supply-side effects or productivity growth. When wages constitute more of national income, the effects typically enhance consumption and reduce investment and net exports. The magnitude of these effects depends on each country's institutional framework and the degree of openness of its economy. If the net effect on economic growth is negative, the demand regime is wage-led; otherwise it is profit-led (Onaran and Galanis 2012). Previous studies acknowledge these results. Onaran and Galanis (2012) found that global Gross Domestic Product (GDP) would rise by $3.05 \%$ if all wage-led countries, notably in Europe, the United Kingdom (UK), the United States (US), Japan, Turkey, and Korea, returned to their 1972 peaks in wages as a 
share of national income.

This study does not seek to prove whether EU countries are wage- or profit-led (i.e., whether wage moderation enhances or hinders economic growth). Instead, we base our arguments on extant empirical studies showing that the EU has maintained real wages below productivity and that this strategy does not promote EU-wide economic growth. We advocate changing the EU's wage-moderation strategy. We confirm the central idea in the post-Keynesian/post-Kaleckian demand-led model developed by Bhaduri and Marglin (1990), which argues that high real wages generate high effective demand, against the view that high labor costs discourage production (Lavoie and Stockhammer 2012, Onaran and Galanis 2012, Cynamon and Fazzari 2015).

The study proceeds as follows. Section II reviews the relevant literature. Section III provides the background of wages as a share of national income and economic growth in the EU. Section IV recognizes two growth models used by EU countries, both based on moderating wages as a share of national income. Section V analyses export-led and debt-led strategies by main determinants of economic growth. Section VI offers recommendations for changing the EU's wage-based growth strategy.

\section{Literature Review}

Wage moderation as an economic growth strategy is ambiguously defined in the literature. Blanchard (2000) applies the concept in an economy with a balanced growth path. Theory defines it as restraining the growth in average wages below growth in productivity. As an economic practice, wage moderation dates to the mid-1980s, when the Netherlands and Ireland used the strategy to reverse an upward trend in unemployment, which was observed since the late 1960s. They were followed by France, Spain, Italy, and Germany in the late 1990s.

The International Monetary Fund (IMF) attributes wage moderation plus changes in labor policies and structural conditions to ending the upward trend in unemployment in those countries (Estevao and Nargis 2002). However, Blanchard (2000) attributes this evolution in wages and unemployment to erosion in European workers' bargaining power since the mid-1980s, and later literature also supports this argument. Numerous studies confirmed that the EU as a whole exemplifies a wage-led economy. They include 
Stockhammer et al. (2009) for the Euro area, Onaran and Obst (2015) for the EU15, Onaran and Galanis (2012) for the Euro area and other developed countries, Storm and Naastepad (2012), Onaran et al. (2011), Hein and Vogel (2008), Naastepad and Storm (2007) for Germany, Naastepad and Storm (2007) for France and Italy, and Bowles and Boyer (1995) for the UK. The main conclusions appear in Table 1.

These studies show that large economies (the UK, Germany, France, Italy, and Spain) and some small economies (Greece, Portugal, Sweden, Finland, the Netherlands, and Luxemburg) are wage-led. Four small economies-Ireland, Austria, Belgium, and Denmark - are profit-led in isolation. That is, they could grow with a rise in profit as a share of national income if they are the only countries doing so. However, it is misleading to analyze EU member states in isolation as the same wage moderation policies have been implemented in all countries simultaneously.

Overall, a simultaneous $1 \%$ point decline in wage share in all countries leads to a $0.30 \%$ decline in GDP among all EU15 countries (Onaran and Obst 2015). The negative effect of the joint race to the bottom on growth ranges between $0.07 \%$ in Ireland and $1.03 \%$ in Greece. Ederer and Stockhammer (2007) identified a profit-led demand regime for France and Bowles and Boyer (1995) did so in Germany, France, and Japan. However, they did not apply difference or error-correction models, and their results suffer from unit root issues. Stockhammer and Onaran (2004) estimated a structural Vector Autoregression (VAR) model for the US, UK, and France and concluded that income distribution exerts weak and statistically insignificant effects on demand and employment. Although VAR deals adequately with simultaneity, it is less adept at identifying the effects and individual behavioral equations. Therefore, results are hard to compare.

Because of data insufficiencies, few empirical analyses examine the Central and Eastern European (CEE) nations that joined the EU during its enlargements in 2004, 2007, and 2013 (the Czech Republic, Estonia, Hungary, Latvia, Lithuania, Poland, Slovakia, Slovenia, Bulgaria, Romania, and Croatia). We call this group the CEE countries. However, Podkaminer (2013) and Lissowska (2014) supported the argument that real unit labor costs were, in principle, negative in post-transition countries, meaning growth of labor costs only partly covered growth in labor productivity. This gap was substantially larger for some countries (Bulgaria, Poland, Romania, Slovenia) than for the EU-15 in the period before the financial crisis. Primary conclusions from the literature review are in Table 1. 
Table 1. Summary of the academic literature

\begin{tabular}{|c|c|c|}
\hline Author & Conclusion & Model / Countries covered \\
\hline $\begin{array}{l}\text { Onaran and } \\
\text { Obst } 2015\end{array}$ & $\begin{array}{l}\text { Simultaneous decline in the wage share by } 1 \% \\
\text { point in all countries leads to a decline in the EU } 15 \\
\text { GDP by } 0.30 \% \text {. In Ireland, the decline would be } \\
0.07 \% \text { and in Greece } 1.03 \% \text {. }\end{array}$ & $\begin{array}{l}\text { The single equation approach } \\
\text { for EU-15. }\end{array}$ \\
\hline $\begin{array}{l}\text { Onaran and Galanis } \\
2012 \text { (International } \\
\text { Labor Organization) }\end{array}$ & $\begin{array}{l}\text { Euro area as well as Germany, France and } \\
\text { Italy are wage-led economies. Increase in the } \\
\text { profit share by } 1 \% \text { point in analyzed countries } \\
\text { (including } 12 \text { EU countries) leads to a } 0.36 \% \\
\text { decline in global GDP. }\end{array}$ & $\begin{array}{l}\text { The single equation approach } \\
\text { used for sixteen developed } \\
\text { and developing countries } \\
\text { (including EU-12). }\end{array}$ \\
\hline $\begin{array}{l}\text { Ederer and } \\
\text { Stockhammer } 2007\end{array}$ & France is a profit-led economy. & $\begin{array}{l}\text { Single equation approach for } \\
\text { France. }\end{array}$ \\
\hline $\begin{array}{l}\text { Stockhammer and } \\
\text { Onaran } 2004\end{array}$ & $\begin{array}{l}\text { Impact of income distribution on demand and } \\
\text { employment is very weak and statistically } \\
\text { insignificant. }\end{array}$ & $\begin{array}{l}\text { Structural VAR model used for } \\
\text { US, UK and France. }\end{array}$ \\
\hline Taylor 1996 & $\begin{array}{l}\text { Profit-led in industrialized economies and wage- } \\
\text { led in developing countries. }\end{array}$ & No econometric model. \\
\hline $\begin{array}{l}\text { Hein and Kramer } \\
1997\end{array}$ & $\begin{array}{l}\text { Advanced capitalist countries have been wage- } \\
\text { led. }\end{array}$ & No econometric model. \\
\hline $\begin{array}{l}\text { Bowles and Boyer } \\
1995\end{array}$ & $\begin{array}{l}\text { France, Germany and Italy are weakly profit- } \\
\text { led, whereas UK and US are wage-led, but their } \\
\text { results suffer from econometric problems such } \\
\text { as unit root issues; they do not apply difference } \\
\text { or error correction models. }\end{array}$ & $\begin{array}{l}\text { The single equation approach } \\
\text { for selected countries: France, } \\
\text { Germany and Italy, UK and } \\
\text { US. }\end{array}$ \\
\hline Lissowska 2014 & $\begin{array}{l}\text { The tendency of wage moderation in the case } \\
\text { of post-transition countries before } 2008 \text { was } \\
\text { particularly acute in Bulgaria, Romania, Slovakia. }\end{array}$ & $\begin{array}{l}\text { No econometric model. Focus } \\
\text { on } 10 \text { CEE countries without } \\
\text { Croatia. }\end{array}$ \\
\hline Podkaminer 2013 & $\begin{array}{l}\text { Evidence of repression of wages in CEE countries } \\
\text { especially in Lithuania and Bulgaria. }\end{array}$ & $\begin{array}{l}\text { No econometric model ( } 10 \mathrm{CEE} \\
\text { countries without Croatia). }\end{array}$ \\
\hline
\end{tabular}




\section{Wage Share and Growth Performance in the EU}

The tendency toward wage repression in the EU was set in 1975, and the share of wages in national income has been decreasing. The years 1974 1975 also mark the end to the post-war full-employment era. The average share of wages as a percentage of GDP peaked at $65 \%$ in 1975 and declined to $55 \%$ in the past decade for the EU-15 (Figure 1).

\section{Figure 1. Average adjusted wage share and GDP annual growth of EU-15}

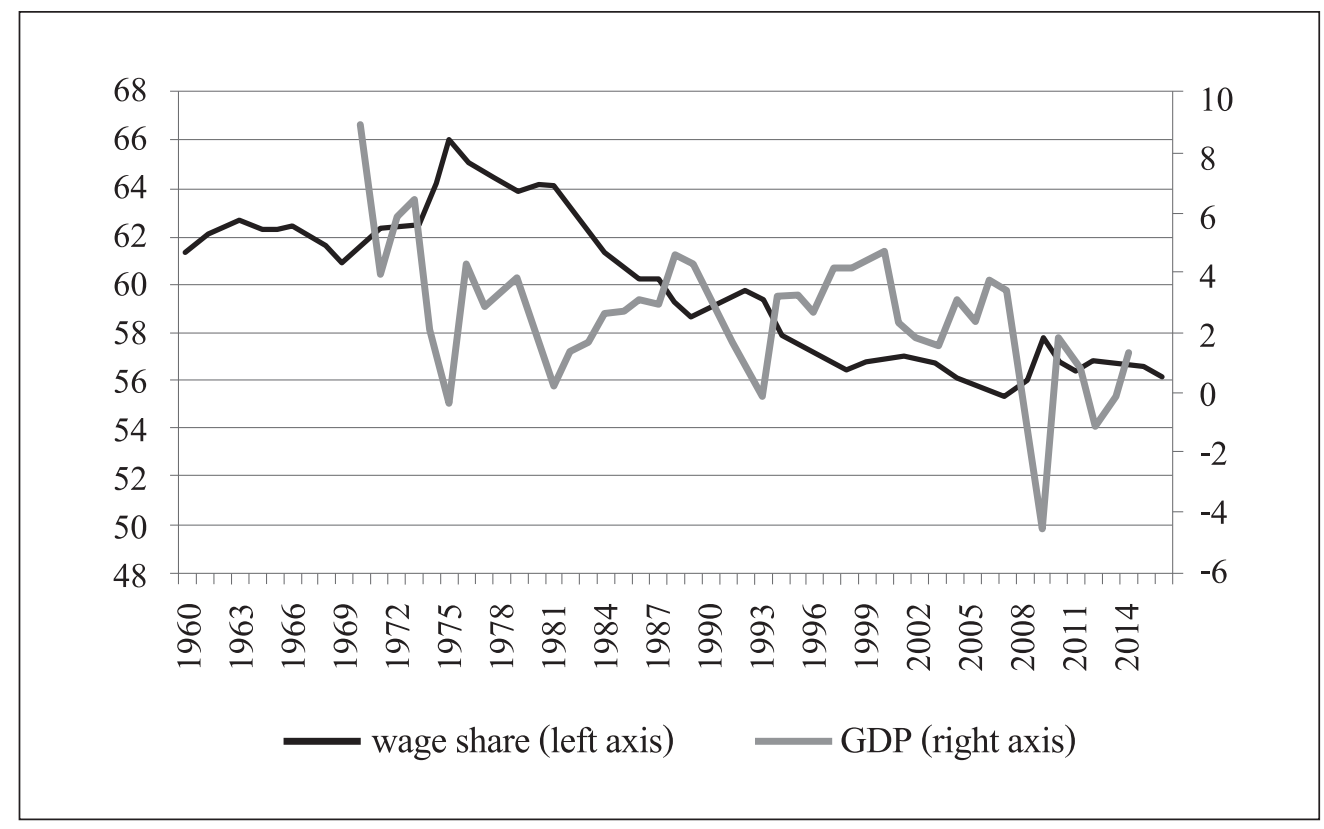

(Source) AMECO Database (Annual Macro-economic Database of the European Commission`s Directorate General for Economic and Financial Affairs), item ALCDO, http://ec.europa.eu/economy_finance/ ameco/user/serie/ResultSerie.cfm, item UVGD, http://ec.europa.eu/economy_finance/ameco/user/serie/ ResultSerie.cfm.

The wage share declines in majority of the countries and is pronounced between the early 1980s and mid-2000s. The decline is more moderate in Belgium, Denmark, and Luxembourg and relatively less in the UK. However, this finding may reflect sharp increases in managerial income. Overall, the share of wages in national income has declined roughly $10 \%$ points in the EU-15 countries between their peaks in the mid- 
1970s and 2015 (Onaran and Obst 2015). This decline has not enhanced economic growth rates, which have declined since 1973 among the EU-15. Growth has become anemic and irregular, and in the last decade, it has been below the average value of $2 \%$ points.

Although a decreasing wage share might be expected to enhance labor productivity and employment, evidence indicates otherwise. Figure 2 shows continuously rising unemployment in the EU-15, reaching its peak (11.1\%) in 2013.

\section{Figure 2. Unemployment rate in EU-15}

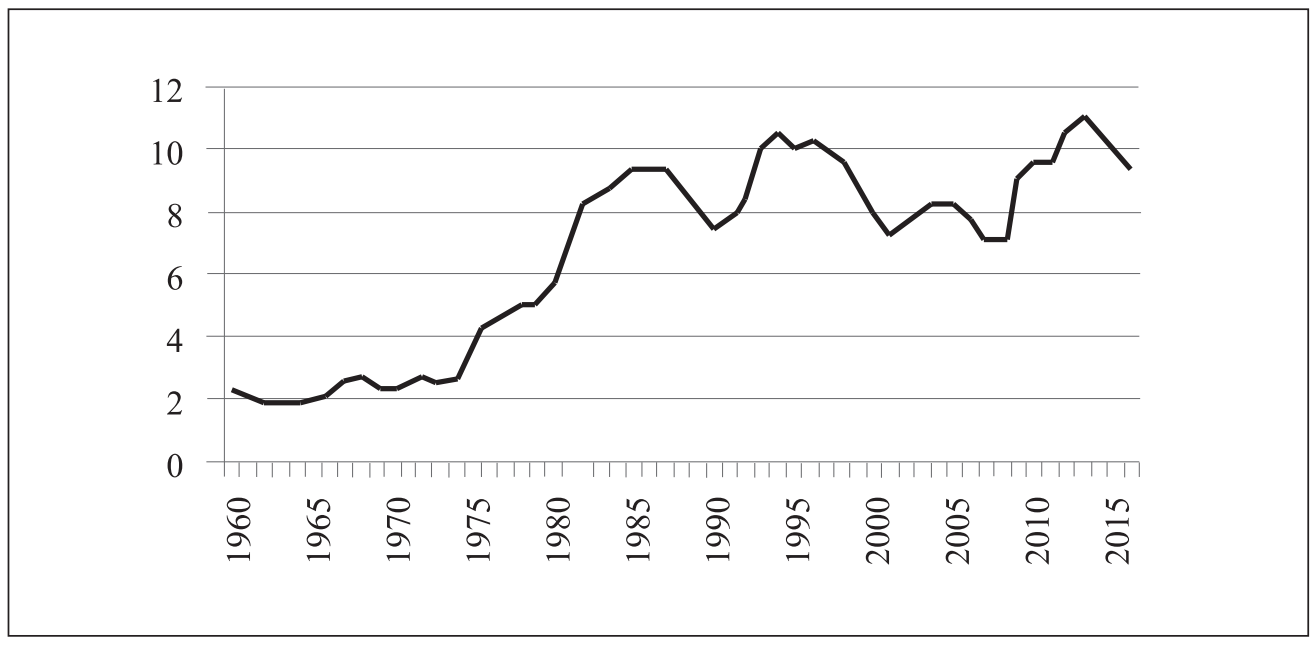

(Source) AMECO Database (Annual Macro-economic Database of the European Commission's Directorate General for Economic and Financial Affairs), item ZUTN, http://ec.europa.eu/economy_finance/ ameco/user/serie/ResultSerie.cfm.

Another link between suppressed wages and persistent unemployment is that the European Central Bank (ECB) tightened interest rates between the 1970s and 2005. Long fearing inflation above $2 \%$, the ECB has been a second guardian of the policy responsible for suppressing wages and maintaining persistent high unemployment (Podkaminer 2015).

The average wage share as a percentage of GDP among CEE countries also has trended downward. Figure 3 indicates it has declined from $60 \%$ to approximately $50 \%$ and flattened during the previous decade and longer. 
Figure 3. Average adjusted wage share and annual GDP growth of CEE countries

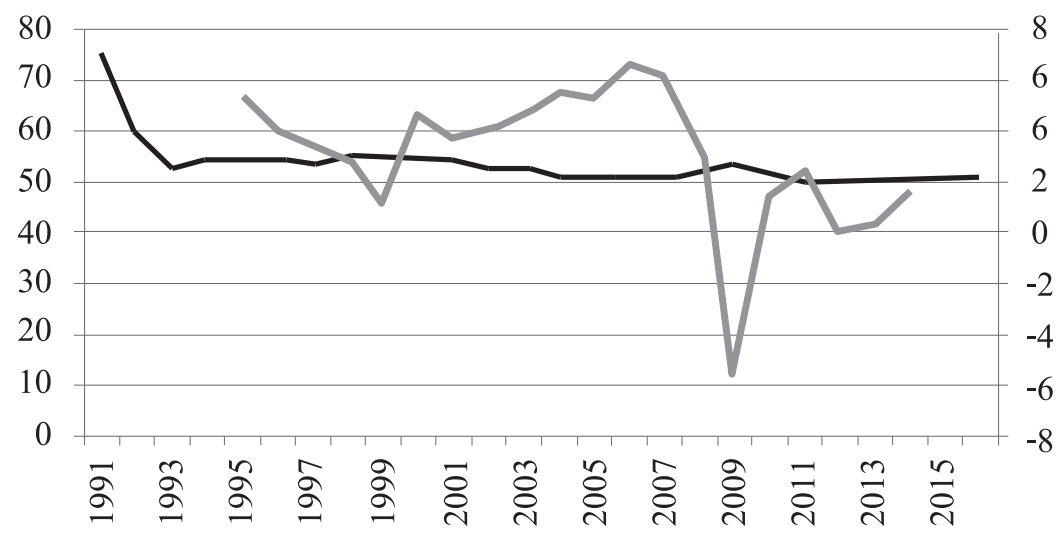

wage share (left axis) - GDP (right axis)

(Source) AMECO Database (Annual Macro-economic Database of the European Commission`s Directorate General for Economic and Financial Affairs), item ALCDO, http://ec.europa.eu/economy_finance/ ameco/user/serie/ResultSerie.cfm item UVGD, http://ec.europa.eu/economy_finance/ameco/user/serie/ ResultSerie.cfm.

The liberalization of most prices in CEE economies and the freedom to engage in trade during their transformation to market economies spurred inflation. The initial inflation was not followed by commensurately rising wages and other incomes (e.g., pensions), and real wages eroded enormously. The effect on employment was also negative (Figure 4). 


\section{Figure 4. Unemployment rate in CEE countries}

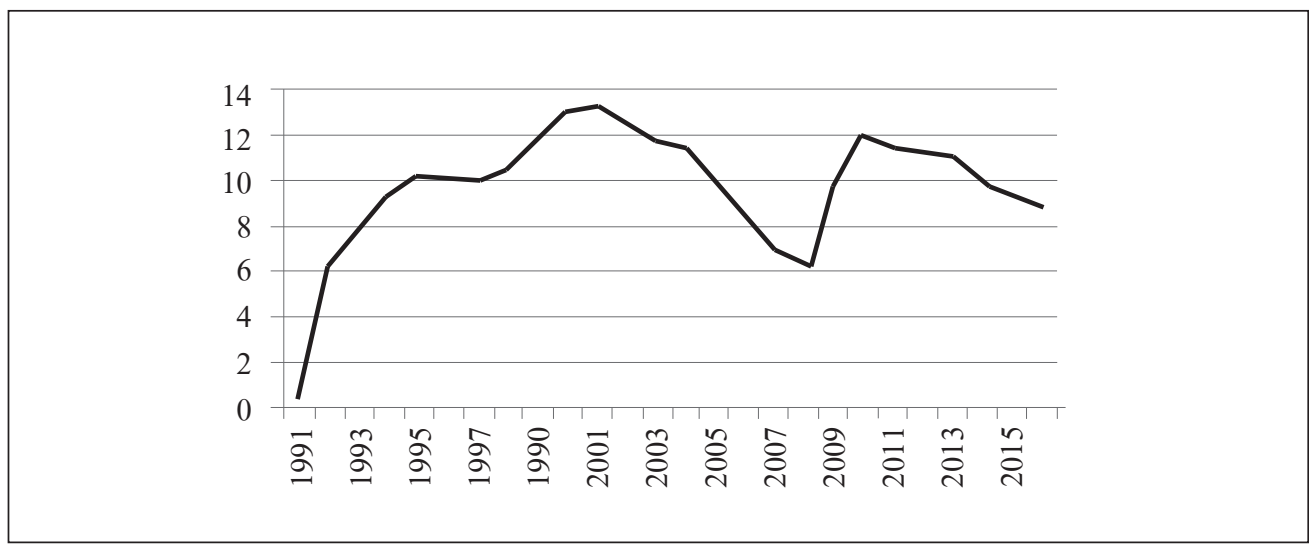

(Source) AMECO Database (Annual Macro-economic Database of the European Commission`s Directorate General for Economic and Financial Affairs), item ZUTN,_http://ec.europa.eu/economy_finance/ ameco/user/serie/ResultSerie.cfm.

These countries' painful economic transformations to market economies were followed by EU integration. Integration strongly incentivized economic convergence with Western Europe, followed by political integration, market liberalization, trade integration, financial integration, and attraction of FDI and foreign savings. ${ }^{1}$ Marzinotto (2012) examined growth effects of the EU cohesion policy during the past decade and finds that EU countries are converging, but with group and country variations in economic performance. Annual GDP growth rates of CEE countries indicate that weighted average growth has been unimpressive. The difference with respect to the EU28 is $1.59 \%$ points during $1995 \sim 2013 .^{2}$ A difference exceeding $2 \%$ points appears only during the pre-crisis period 1995 2007, when CEE economies experienced significantly higher growth than that of the Western European countries, as a result of nominal convergence. However, this result is mainly attributable to their lower starting points.

Removal of cross-border barriers facilitated foreign trade and direct investment, including technology transfer and spillovers. Technology transfer drove the convergence by enabling upgrades in product quality and improving organizational structures and practices. When financial markets opened to foreigners, Western European groups

\footnotetext{
'See Becker et al. (2010), Bennett, Estrin, and Urga (2007), Godoy and Stiglitz (2006), Falcetti, Lysenko, and Sanfey (2006), Fidrmuc and Tichit (2009), Hare and Turley (2013), Kornai (2006), and Rusinova (2007).

${ }^{2}$ World Bank Development Indicators Database, http://data.worldbank.org/data-catalog/world-development-indicators.
} 
acquired the region's banks and attained dominant market positions in most countries. Net pre-crisis capital inflows exceed those of any other emerging or developing region (Becker et al. 2010).

Nonetheless, nominal convergence exhibits no significant progress toward growth in EU countries. During the 2008 2013 crisis period, rates of economic growth declined in most CEE countries (Figure 3) even though the rate of nominal convergence remained positive $(0.25 \%$ points $)$, largely because of Poland and Slovakia.

The economic growth model of the CEE countries was resource-intensive and debtintensive. It supported only short-term growth and proved ineffective. The external liberalization that underpinned the model generated external imbalances, bubbles driven by capital inflows, and unstable growth. The crisis showed that the model used during EU accession cannot support these countries' further growth.

\section{Wage Moderation Strategy in the EU}

The former is being used by the EU-15 countries - the old EU countries that joined the union before 2004. They long have encouraged wage moderation by explicitly promoting real wage growth below productivity growth. Absent domestic demand supported by healthy wage increases, Europe's core economies-Germany and its smaller cousins - relied on exports to drive growth (Stockhammer 2011). Of course, this is a general conclusion about the EU-15. Southern European countries (Italy, Portugal, Greece, and Spain) might share more characteristics with the debt-led growth strategy. However, CEE countries had low real wages and relied on foreign financial inflows for economic growth. Lacking decent wage increases, credit-financed consumption and residential investment became key sources of demand growth (hence the term debtled growth). Although it initially seems that CEE countries have used a growth strategy different from the EU-15, they accepted its wage moderation doctrine upon entering the EU. Podkaminer (2015), Arpaia et al. (2007), and Bibow (2013) showed that wages throughout the EU are suppressed by internal competition imposed by Germany. It is noteworthy that globalization-outsourcing and offshoring production to low-wage/

\footnotetext{
${ }^{3}$ World Bank Development Indicators Database, http://data.worldbank.org/data-catalog/world-development-indicators.
} 
low-tax destinations - has not caused the EU's decline in wages as a share of national income.

The strategy promoted maintaining real wage growth below growth in labor productivity as it would lead to a more productive and dynamic economic system (European Commission 2006). Contrary to expectations, both strategies were associated with poor growth in both groups of countries and the entire EU. This is evident in the aftermath of the financial crisis and almost complete knockdown of CEE countries and their growth model.

\section{Export-led vs. Debt-led Strategy}

To see how the falling wage share affects economic growth and the difference between export- and debt-led strategies, we discuss private consumption, investment, trade balances, and government spending as determinants of economic growth in EU-15 and CEE countries.

\section{A. Private consumption}

During 1960 2015 (including forecasts for 2016), private consumption in the EU15 declined. The deceleration in wage share and rise in the unemployment rate stand as the main reasons for decreasing private consumption among EU-15 countries. Figure 5 shows the 10-year average private consumption in the EU-15 falling gradually. 
Figure 5. Private consumption in EU-15

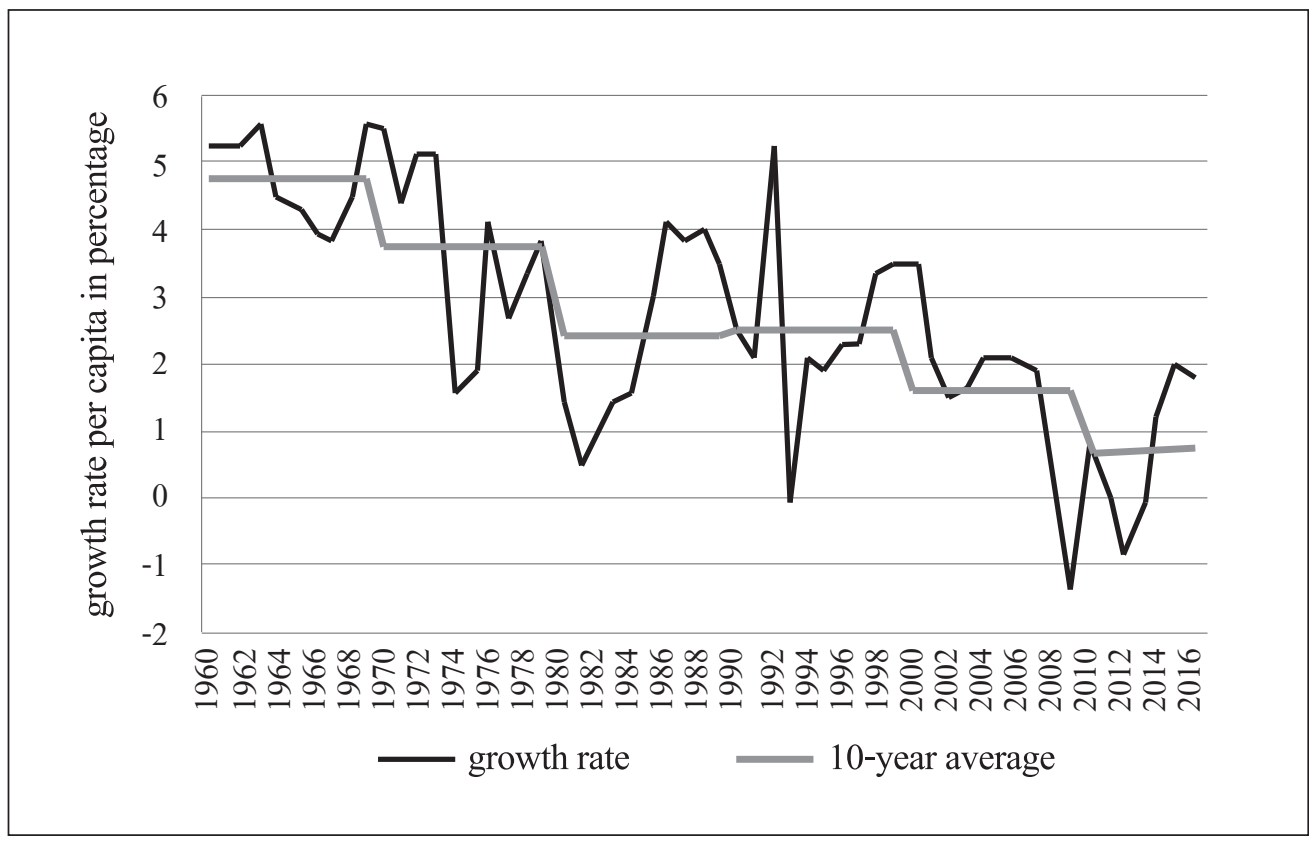

(Source) AMECO Database (Annual Macro-economic Database of the European Commission`s Directorate General for Economic and Financial Affairs), item OCPH, http://ec.europa.eu/economy_finance/ ameco/user/serie/ResultSerie.cfm.

Figure 6 shows that private consumption in CEE countries trended upward before the financial crisis, fueled by credit from foreign institutions until 2008. Although recovering, post-crisis private consumption in CEE countries has not reclaimed pre-crisis levels. 
Figure 6. Private consumption in CEE

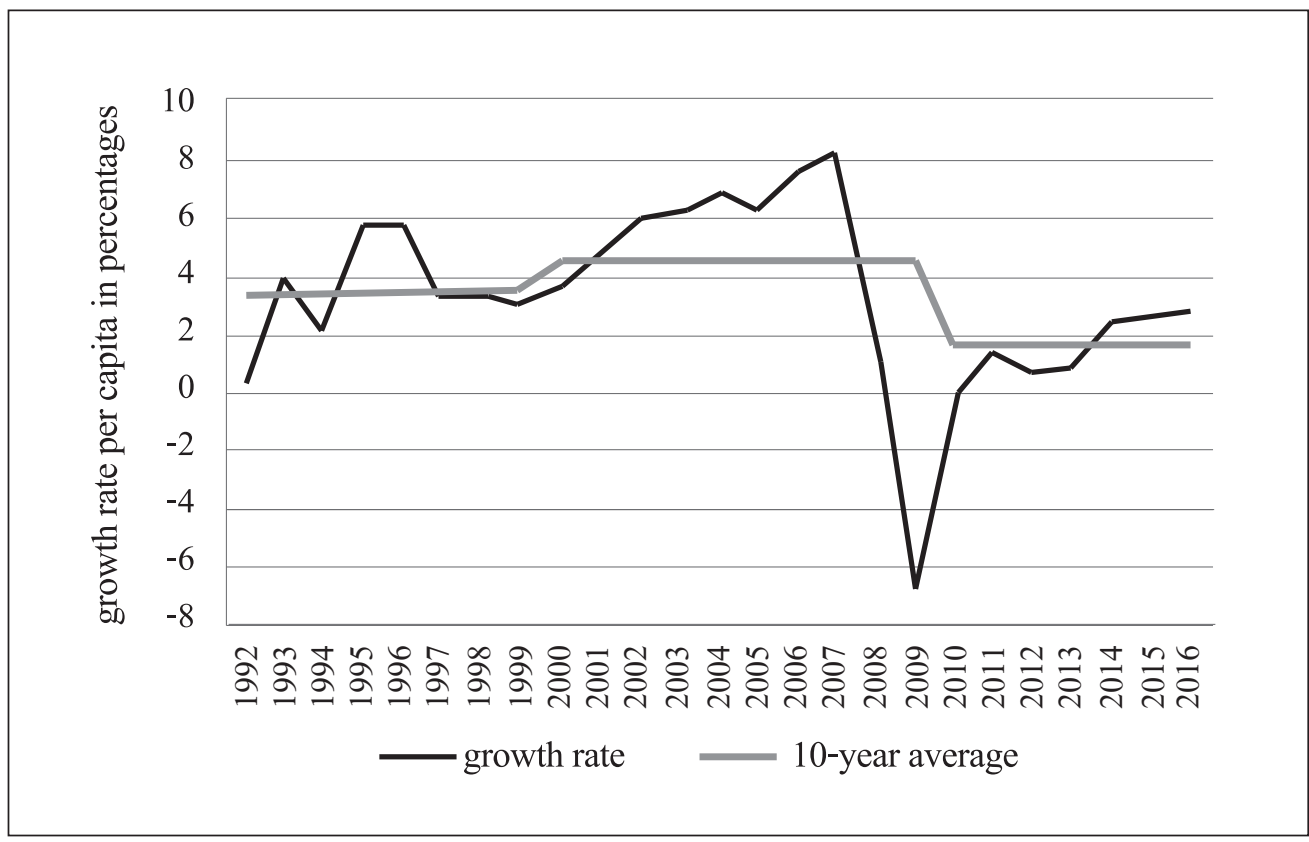

(Source) AMECO Database (Annual Macro-economic Database of the European Commission`s Directorate General for Economic and Financial Affairs), item OCPH, http://ec.europa.eu/economy_finance/ ameco/user/serie/ResultSerie.cfm.

Tridico (2012) underlines the impact of declining wages on unstable growth. Households embraced the consumerism of US and Europe and borrowed to sustain consumption that was not supported by stable employment and growing wages. The price was economic instability. This is evident in the CEE countries. Household indebtedness in CEE countries did not exceed that in the Euro zone, but in 2001 it had increased drastically in relation to household income. For example, indebtedness of Lithuanian households was 15 times greater in 2011 compared with that in 2001. Average indebtedness of households in CEE countries was five times greater in 2011 than that in 2001 (Lissowska 2014).

In the following, we correlate the inflow of foreign credit and household indebtedness in CEE countries. Figure 7 shows that rising indebtedness positively correlates with the size of inflow of foreign credits in the indicated countries. 


\section{Figure 7. Correlation between inflow of foreign credits and change of debt to income}

(2001 2008)

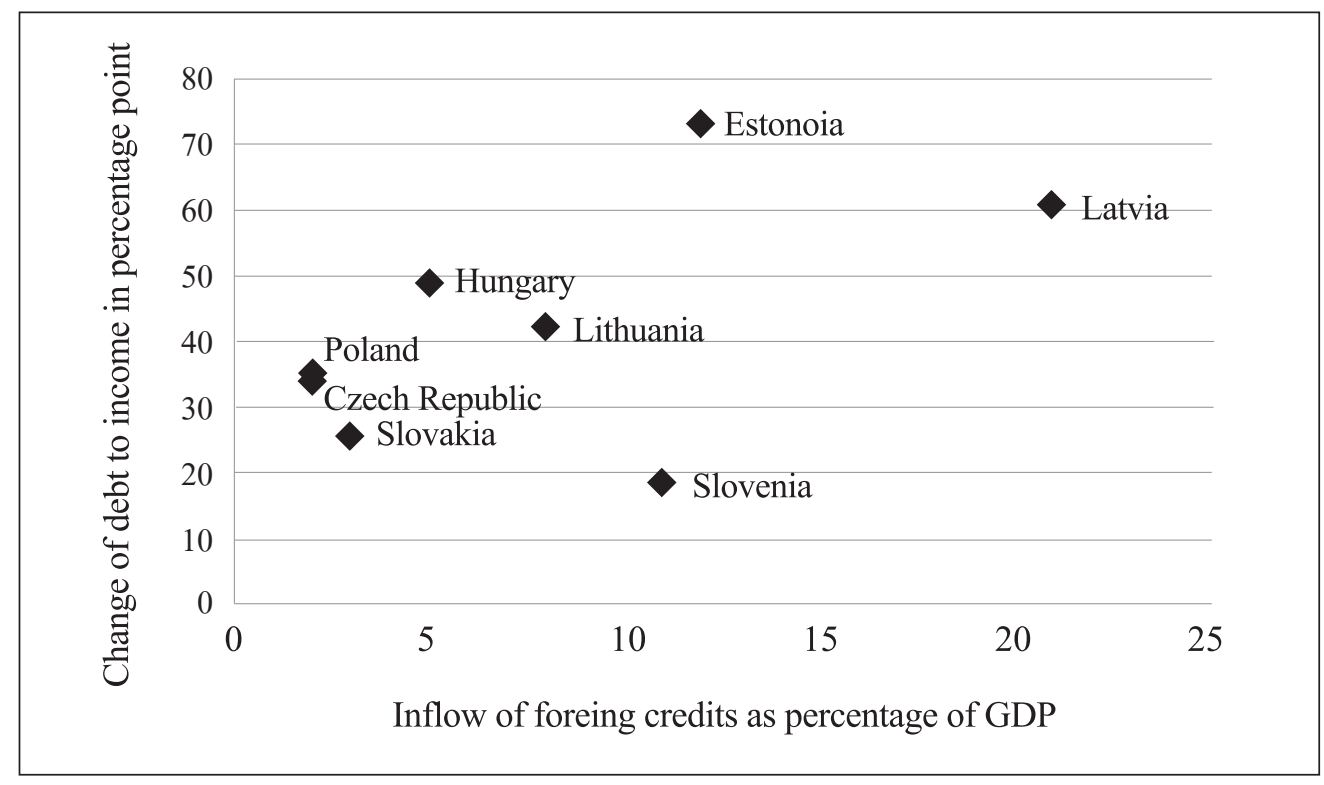

(Source) Author's calculations, data from Lissowska, "Welfare against Growth Gains in Post-Transition Countries. What are the Consequences for Stability?” Economics: Open-Assessment E-Journal, 8 2014:1-37, and http://appsso.eurostat.ec.europa.eu/nui/show.do?dataset=bop_q_c\&lang=en, http:// appsso.eurostat.ec.europa.eu/nui/show.do?dataset=nama gdp c\&lang=en.

In sum, inflow of foreign credit fueled consumption preceding the crisis (Lissowska 2014). This trend is notable for Latvia, Estonia, Lithuania, and Hungary in the upper right of Figure 9. The sluggish recovery of growth in private consumption post-crisis underlines that the growth strategy of CEE countries was unstable and needs changing.

\section{B. Investment}

The EU strategy of wage-moderated growth was expected to suppress private consumption and to boost the EU's international competitiveness by increasing investments and net exports. However, the commonly used measure of gross capital formation as a share of GDP among the EU-15 declines over the observed period. The contribution of gross fixed capital formation to GDP is high and stable until 1973, after which it became volatile and slowed thereafter (Figure 8). 
Figure 8. Gross capital formation

8a. EU-15

(\% of GDP)

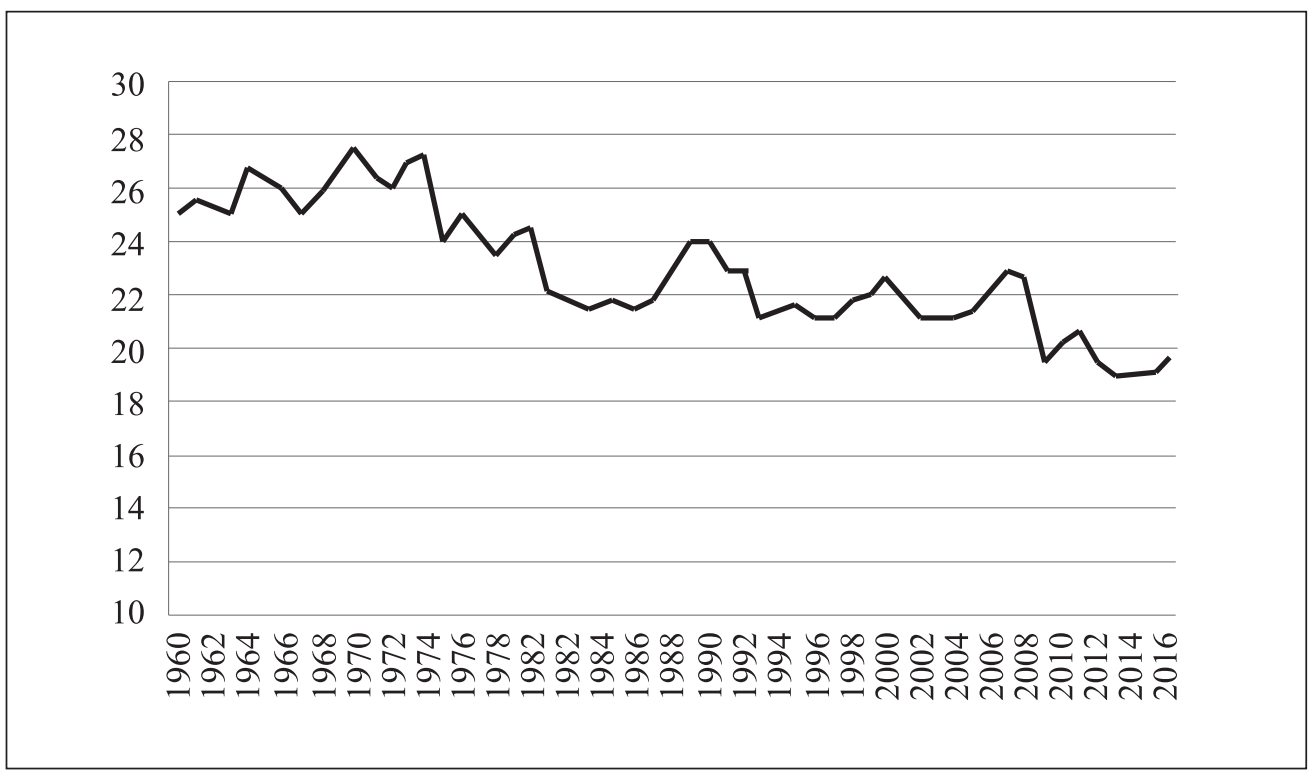

8b. CEE

(\% of GDP)

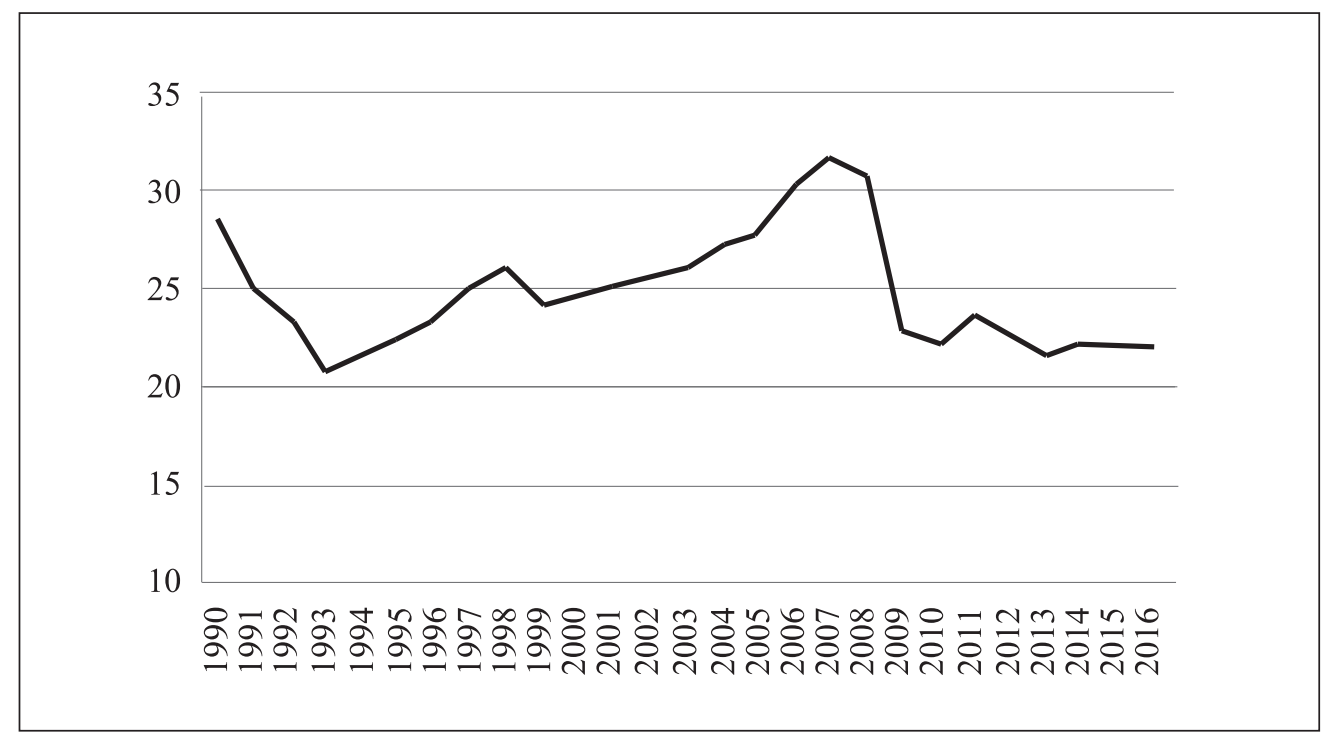

(Source) AMECO Database (Annual Macro-economic Database of the European Commission`s Directorate General for Economic and Financial Affairs), items UITT http://ec.europa.eu/economy_finance/ameco/ user/serie/ResultSerie.cfm, items UVGD http://ec.europa.eu/economy_finance/ameco/user/serie/ ResultSerie.cfm. 
Figure 9b, however, presents the opposite situation. The indicator of gross capital formation as a percent of GDP rises in the CEE countries until the onset of the financial crisis and thereafter flattens to $20 \%$ from GDP. This evidence, taken alongside average GDP growth, indicates that the debt-led strategy could not generate real recovery and proved to be unstable.

If we analyze the reasons for the sluggish recovery of the investments in CEE countries, we come to the evidence that most of the financing came from foreign direct investments. For most CEE countries, FDI was the most important source of financing. For example, in Bulgaria from 1995 until 2008, it was 44.63\% of total gross fixed capital formation and accounted for 10\% annual growth of FDI as percentage of GDP (Table 2).

Table 2. FDI inflows in the CEE countries

(1995 2008)

\begin{tabular}{|c|c|c|}
\hline & FDI as percentage of GDP & $\begin{array}{c}\text { FDI as percentage of gross fixed } \\
\text { capital formation }\end{array}$ \\
\hline Bulgaria & 9.98 & 44.63 \\
\hline Czech Republic & 5.78 & 20.86 \\
\hline Estonia & 8.37 & 27.66 \\
\hline Latvia & 5.30 & 23.39 \\
\hline Lithuania & 3.85 & 16.92 \\
\hline Hungary & 5.39 & 23.94 \\
\hline Poland & 3.92 & 19.43 \\
\hline Romania & 5.45 & 23.89 \\
\hline Slovenia & 1.98 & 7.88 \\
\hline Slovakia & 5.53 & 20.77 \\
\hline
\end{tabular}

(Source) http://appsso.eurostat.ec.europa.eu/nui/show.do?dataset=nama_gdp_c\&lang=en, http://appsso.eurostat. ec.europa.eu/nui/show.do?dataset=bop_q_c\&lang=en.

It is unclear why escalating investment before the financial crisis did not sustain economic growth in CEE countries and their post-crisis recovery. That interesting issue 
lies outside our purpose, which is to stress how integration and convergence of CEE countries with the EU-15 influenced the acceptance of its wage moderation strategy.

The relation between growth in labor productivity and employee income in CEE countries exhibits a negative trend. Growth in labor productivity was only partly accompanied by growth in labor costs.

Table 3. Cumulated change of labor productivity and labor cost

(Initial year=1)

\begin{tabular}{|c|c|c|c|c|}
\hline & $2008 / 2000$ & $2013 / 2008$ & $2008 / 2000$ & $2013 / 2008$ \\
\hline & $\begin{array}{r}\text { Real labour productivty } \\
\text { per person employed }\end{array}$ & \multicolumn{2}{|c|}{ Real unit labor cost } \\
\hline EU-15 & 1.07 & 1.02 & 0.98 & 1.08 \\
\hline CEE average & 1.44 & 1.10 & 1.00 & 1.06 \\
\hline Bulgaria & 1.34 & 1.14 & 0.95 & 1.33 \\
\hline Czech republic & 1.33 & 1.01 & 1.05 & 1.06 \\
\hline Estonia & 1.43 & 1.14 & 1.11 & 1.04 \\
\hline Latvia & 1.47 & 1.15 & 1.15 & 0.90 \\
\hline Lithuania & 1.63 & 1.20 & 1.03 & 0.98 \\
\hline Hungary & 1.32 & 1.02 & 0.98 & 1.11 \\
\hline Poland & 1.28 & 1.18 & $n . a$. & 1.07 \\
\hline Romania & 1.87 & 1.00 & 0.84 & 0.99 \\
\hline Slovenia & 1.28 & 1.07 & 0.97 & 1.08 \\
\hline Slovakia & 1.45 & 1.10 & 0.95 & 1.06 \\
\hline
\end{tabular}

(Note) Change in unit labour costs corresponds to the change of compensation of employees per number of employees not covered by the change of labour productivity plus the change of the share of employees in total employment.

(Source) http://appsso.eurostat.ec.europa.eu/nui/show.do?dataset=nama_aux_lp\&lang=en, http://appsso.eurostat. ec.europa.eu/nui/show.do?dataset=nama_aux_ulc\&lang=en. 
Labor productivity in most CEE countries exceeded that among the EU-15. In 2008, the EU experienced a $0.01 \%$ point average increase in labor productivity over 2000 . Average labor productivity grew more than $0.44 \%$ points in 2008 compared with 2000 in the CEE countries. At the same time, wages in 2008 decreased $0.02 \%$ points in the EU, whereas CEE wages remained largely unchanged from 2000 (Table 3). During the precrisis period, the gap between growth in compensation and growth in labor productivity for Bulgaria, Romania, and Slovakia was substantially greater than that for the EU-15. This factor coincides with intensive FDI inflows for the three countries. Other factors, likely higher technology levels, seem to underpin FDI inflows in Estonia, the Czech Republic, and Hungary, where labor cost advantages were less substantial (Lissowska 2014).

\section{Trade balances}

The EU holds the dominant share in world trade of goods but is gradually losing that position. Its share of world trade in goods declined from $17.9 \%$ in 2004 to $14.8 \%$ in 2014 while China's share rose from $8.4 \%$ to $14.2 \%$ (Eurostat Database).

We argue that this situation arises from structural imbalances in the EU and that the EU cannot sustain its position as a leading trade player and major net exporter. The EU's trade balance results from Germany, Luxemburg, Finland and the Netherlands, which traditionally achieve trade surpluses. Greece, Portugal, Spain, Latvia, and most CEE countries traditionally maintain trade deficits (Table 5).

The indicated countries achieve trade surpluses by pursuing deflationary policies such as suppressing nominal wages below productivity. There are limits to these deflationary beggar-thy-neighbor policies, which adversely affect the deficit EU countries and others outside the EU. A small country (e.g., Luxembourg) can run current account surpluses over extended periods without perceptible impacts on trading partners. Germany and other large countries are unlikely to have indefinitely large current account surpluses because Germany's current account surplus is the current account deficit of its partners. Thus, within a monetary union, running current account surpluses is possible if the same attempts fail in other Euro-area countries. Germany's policy of suppressing wages is destructive for other EU members and pressures them into keep wages low. In addition, the beggar-thy-neighbor policy is self-defeating because it implies accumulating the foreign debt of countries with persistent trade deficits. Once it is acknowledged that 
debt is unsustainable, growth in countries with persistent trade surpluses inevitably will suffer, and creditor countries must write off their impaired assets (Laski and Podkaminer 2012). To foster competitiveness, the Euro-Plus Pact and the November-drafted SixPack state that nominal-wage growth should coincide with labor productivity growth in member states. This is one measure that allows fair and real productivity-wage levels and fair policies of EU member states. It is important to acknowledge that the Stability and Growth Pact was designed with no mechanisms for monitoring external imbalances and for preventing this situation. Thus, even though the EU as a whole has a positive trade balance, the situation is unsustainable without adequate regulation and supervision of countries' external imbalances and insistence on deflationary policies. Examining trade balances of CEE countries reveals that growth in consumption and investments has boosted imports. They were imbalanced against exports, creating additional vulnerability through current account deficits (Table 4). Only stable exporters, Slovenia and the Czech Republic, escaped high current account imbalances.

\section{Table 4. Balance of the current accounts}

$(\%$ of GDP)

\begin{tabular}{|c|c|c|c|c|c|c|c|c|c|c|c|c|c|}
\hline CEE countries & 2002 & 2003 & 2004 & 2005 & 2006 & 2007 & 2008 & 2009 & 2010 & 2011 & 2012 & 2013 & $\begin{array}{c}\text { average } \\
2002 ~ 2013\end{array}$ \\
\hline Bulgaria & -2.4 & -5.3 & -6.4 & -11.6 & -17.6 & -25.2 & -23.1 & -8.9 & -1.5 & 0.1 & -0.8 & 1.9 & -8.4 \\
\hline Czech Republic & -5.3 & -6 & -5.1 & -1 & -2 & -4.3 & -2.1 & -2.4 & -3.9 & -2.7 & -1.3 & -1.4 & -3.1 \\
\hline Estonia & -10.6 & -11.3 & -11.3 & -10 & -15.3 & -15.9 & -9.2 & 2.7 & 2.8 & 1.8 & -1.8 & -1 & -6.6 \\
\hline Croatia & -7.3 & -6.1 & -4.1 & -5.2 & -6.6 & -7.1 & -8.7 & -4.9 & -0.8 & -0.8 & 0.1 & 1.2 & -4.2 \\
\hline Latvia & -6.7 & -8.2 & -12.9 & -12.6 & -22.5 & -22.4 & -13.2 & 8.6 & 2.9 & -2.1 & -2.5 & -0.8 & -7.7 \\
\hline Lithuania & -5.1 & -6.7 & -7.6 & -7.1 & -10.6 & -14.4 & -12.9 & 3.7 & 0.1 & -3.7 & -0.2 & 1.5 & -5.3 \\
\hline Hungary & -7 & -8 & -8.7 & -7.5 & -7.4 & -7.3 & -7.3 & -0.2 & 0.2 & 0.4 & 0.8 & 3 & -4.1 \\
\hline Poland & -2.8 & -2.5 & -5.3 & -2.4 & -3.8 & -6.2 & -6.6 & -3.9 & -5.1 & -5 & -3.7 & -1.3 & -4.1 \\
\hline Romania & -3.3 & -5.9 & -8.4 & -8.6 & -10.5 & -13.4 & -11.6 & -4.2 & -4.4 & -4.5 & -4.4 & -1.1 & -6.7 \\
\hline Slovenia & 1 & -0.8 & -2.6 & -1.7 & -1.8 & -4.2 & -5.4 & -0.5 & -0.1 & 0.4 & 3.3 & 6.3 & -0.5 \\
\hline Slovakia & -7.9 & -5.9 & -7.8 & -8.5 & -7.8 & -5.3 & -6.2 & -2.6 & -3.7 & -3.8 & 2.2 & 2.1 & -4.6 \\
\hline
\end{tabular}

(Source) http://ec.europa.eu/eurostat/tgm/table.do?tab=table\&language=en\&pcode=tec00043. 
The positive trends after 2009 for some countries are results of cyclical movements. Countries with high trade deficits before the crisis experienced significant declines in domestic demand and insignificant declines in exports. As these countries' exports are generally low-tech, they face a low elasticity of demand. At the same time, domestic demand began to favor imported products. Exports were unaffected due to the low elasticity of foreign demand and orientation of domestic consumers toward domestic (cheaper) products (Mrak 2010).

\section{Government spending}

Growth in per capita public spending is declining among the EU-15, indicating that fiscal policies supported slowdown of the economic growth before the crisis. Public consumption in CEE countries fell from 2003 until the onset of the crisis. The same trend is evident in public investments and is understandable, as government spending is countercyclical.

Figure 9. Growth rate of public consumption

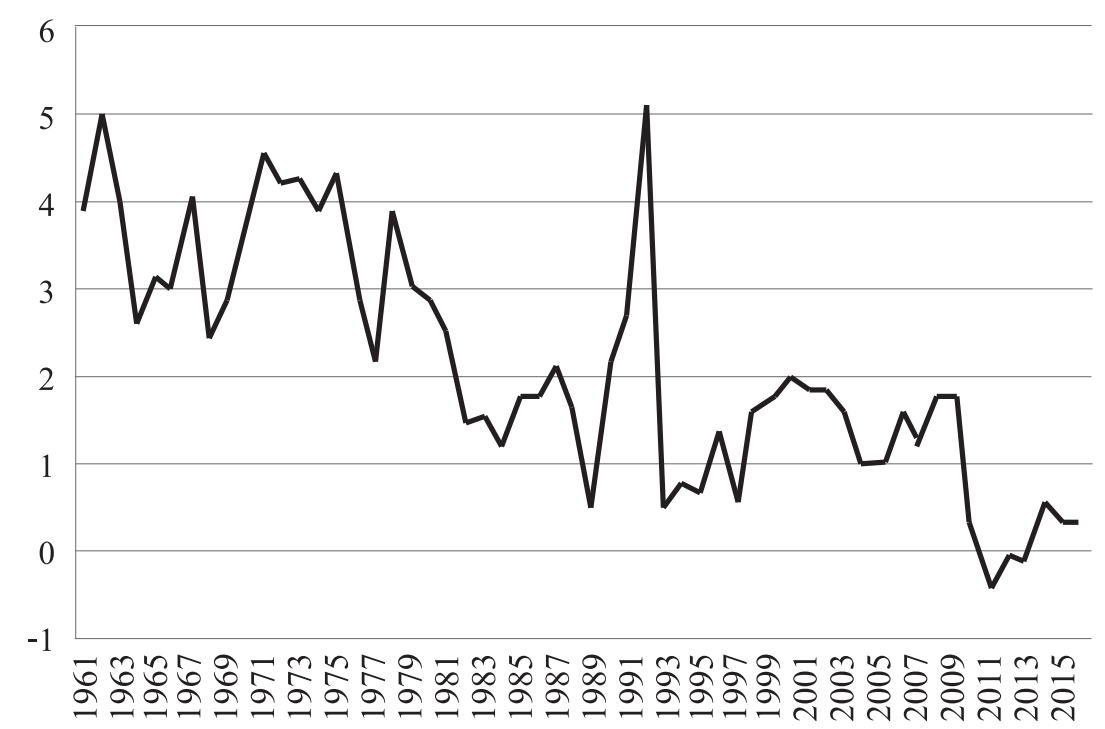




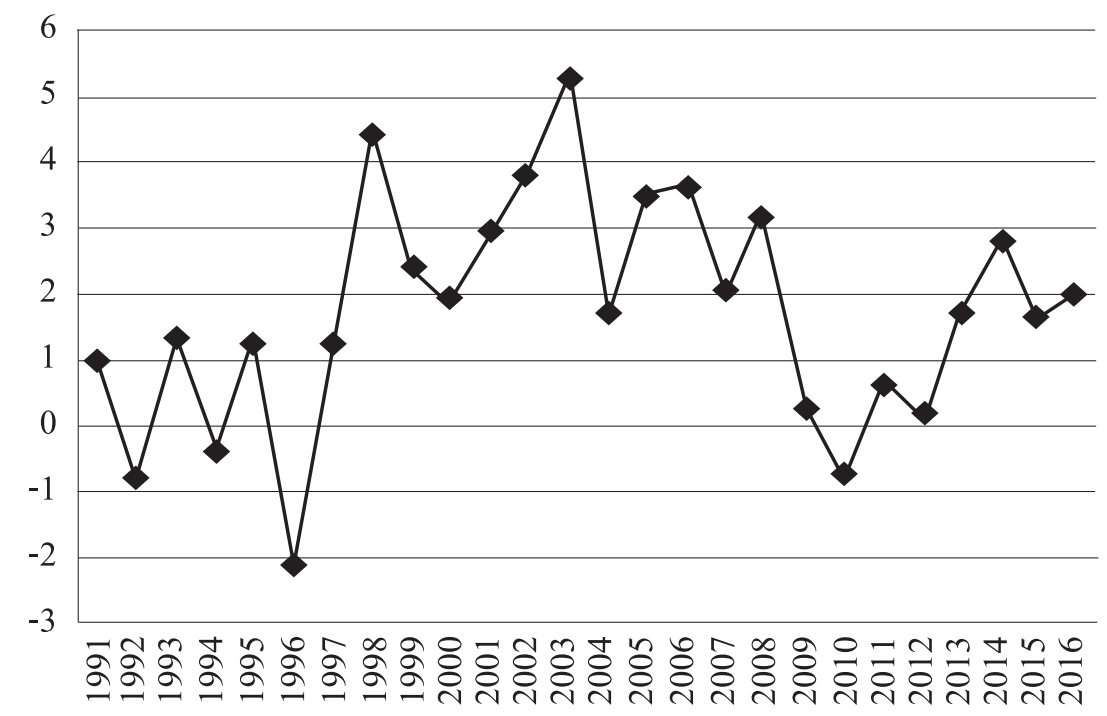

(Source) AMECO Database (Annual Macro-economic Database of the European Commission's Directorate General for Economic and Financial Affairs), item OCTG, http://ec.europa.eu/economy_finance/ ameco/user/serie/ResultSerie.cfm.

Public finances started growing intensively throughout the EU after 2008. We believe that the financial crisis started when households could no longer service their debt, which equaled nearly 100\% of GDP in the EU. Jovanovik and Damjanovik (2014) stated that CEE countries have been living on a credit card that future generations will pay off. Thus, the increase in government debt was the consequence of the crisis, not its cause. The fiscal interventions undertaken by European governments prompted significant increases in public debt in relation to GDP.

The challenge now is to stimulate economic growth given the current large and unsustainable levels of public debt. Pubic spending will most likely rise in the near future to stimulate private sector investment. The architecture of monetary union needs to be maintained by stronger supervision and regulation of the financial sector. During regional integration from a common market to a monetary union, the EU skipped creating an economic union and that omission is evident and symptomatic in the EU's current functioning. 


\section{Conclusion}

Holding wages below increases in productivity decelerated consumption growth among EU-15 countries. Although policymakers expected the repression of wages to increase profits, thus boosting investment, investment also gradually slowed. GDP gains from trade surpluses are unlikely to offset losses from low domestic demand. Among CEE countries, suppressed domestic demand spurred private indebtedness to maintain consumption. Consumption growth and increased investment among most CEE countries boosted imports without countervailing exports that created additional vulnerability through current account deficits. Public spending by EU-15 and CEE countries is also limited because those countries have exceeded EU-mandated limits.

Overall, the EU faces the following situation. Its external imbalances result from deflationary policies by particular member states, which are destructive for all member states. The policy of suppressing wages below productivity is unsustainable. The EU's longstanding policy of wage moderation has produced rising inequality and unemployment.

Sustaining this strategy is unacceptable. According to Onaran (2015), the race to the bottom in wage share generally has wiped out the positive effects on net exports as unit labor costs fall simultaneously in all countries. Moreover, their international competitiveness relative to each other does not change significantly. Storm and Naastepad (2012) concluded that a reasonable order of magnitude is that a $1 \%$ point increase in real wage growth leads to a $0.38 \%$ point growth in labor productivity. Higher real wage growth induces firms to increase labor productivity to protect profitability. Hence, the available evidence suggests real wage growth has a positive long-run effect on labor productivity. This is important for economic policy, as it suggests excessive wage constraint will weaken productivity performance.

To foster competitiveness, the EU should implement the Euro-Plus Pact and the November-drafted Six-Pack. Nominal wage growth should evolve with growth in labor productivity in each member state. This measure to allow real productivity-wage levels and fair policies will accrue benefits to all member states.

Inflation might rise from wage increases, but that is advantageous as the EU is teetering on deflation. Wage increases will help the ECB attain its inflation target of $2 \%$ while stimulating job and economic growth.

Furthermore, the EU needs to overcome problems of coordinating macroeconomic 
policies by institution-building both nationally and for Europe. It is crucial that policies to increase wages join a mix of economic policies to achieve sustainable and balanced growth between EU countries followed by full employment. There is a need for policies that enhance the power of labor and changes in the redistributive policies that stimulate consumption through progressive taxation. Also, completing the European Monetary Union needs stronger architecture, coordinating economic policies and common supervision of the financial sector. We strongly support the establishment of the European Banking Union. The EU should restore the sustainability of public finances and encourage private spending to sustain internal balance. Measures that ensure stronger and more effective economic governance, particularly for the Euro area, with adequate mechanisms to monitor progress and ensure enforcement are needed (Fiscal compact, ESM mechanism, the Six pack, the European Semester, new rules for credit rating agencies).

Nothing will be achieved without unconditional optimality of international flows of goods, services, capital, and labor. The functioning of the single market is essential to achieve wage flexibility, higher investment, and private consumption. The effects of deep integration of the EU have not yet been achieved, and expected benefits may not be realized if changes in the growth strategy are not made.

Received 11 December 2015, Revised 9 March 2016, Accepted 28 April 2016

\section{References}

Bhaduri, Amit and Stephen Marglin. "Unemployment and the real wage." Cambridge Journal of Economics 14 (1990): 375-393.

Bibow, Jörg. "Germany and the Euro land Crisis: The Making of a Vulnerable Haven." Levy Economics Institute Working Paper No.767 (2013): 28-30.

Blanchard, Oliver. "The Economics of Unemployment Shocks, Institutions and Interactions." Lionel Robbins Lectures, London School of Economics (2000).

Bowles, Samuel and Robert Boyer, R. "Wages, aggregate demand, and employment 
in an open economy: an empirical investigation," in Macroeconomic Policy after the Conservative Era. Ed. Larry G. Epstein and Herbert Gintis (Cambridge: Studies in Investment, Saving and Finance, 1995): 112-140.

Cynamon, Barry Z., and Steven M. Fazzari. "Inequality, the Great Recession, and Slow Recovery." Cambridge Journal of Economics (2015): 1-27, accessed February 10, 2016, doi: 10.1093/cje/bev016.

Ederer, Stefan and Engelbert Stockhammer, "Wages and aggregate demand : an empirical investigation for France," Money, Distribution and Economic Policy, ed. Eckhard Hein and Achim Truger. (Cheltenham: Edward Elgar Publishing, 2007), 163190.

Ellis, Luci and Kathryn Smith. "The Global Upward Trend in the Profit Share.” Bank for International Settlements Working Paper No. 231 (2007): 25-32.

European Commission. Directorate-General for Economic and Financial Affairs. "Nominal and real wage flexibility in EMU." Economic paper No. 281 (2007).

European Commission. "Time to move up a gear the new partnership for jobs and growth." European Commission Press Release IP/06/71 (2006).

Hein, Eckhard and Hagen Krämer. "Income shares and capital formation: patterns of recent developments." Journal of Income Distribution 7-1 (1997): 5-28.

Hoffer, Frank and Friederike Spiecker. "Change or Lose Europe." International Labor Organization Global Job Crisis Observatory (2011), accessed March 20, 2016, http:// www.ilo.org/public/libdoc/jobcrisis/download/story108_change_europe.pdf

International Labor Organization. "Making Markets Work for Jobs." International Labor Organization Work Report (2011): 44-60.

International Monetary Fund. "Globalization and Inequality." World Economic Outlook (2007).

International Monetary Fund. "Responding to the Financial Crisis and Measuring Systemic Risks." Global Financial Stability Report (2009).

Jovanovik, Miroslav and Jelena Damnjanovic. "EU Eastern Enlargement: Economic Effects on New Members 2000-2012.” Journal of Economic Integration 29 (2014): 210243, http://dx.doi.org/10.11130/jei.2014.29.2.210. 
Lance, Taylor. "Stimulating global employment growth," Global Unemployment Loss of Jobs in the 90's, ed John Eatwell (New York: ME Sharpe, 1996).

Laski, Kazimierz and Leon Podkaminer. "The basic paradigms of EU economic policymaking need to be changed." Cambridge Journal of Economics 36 (2012): 253-270, doi:10.1093/cje/ber030.

Lavoie, Marc and Stockhammer, Engelbert. "Wage-Led Growth: Concept, Theories and Policies.” International Labor Organization Working Papers No. 41 (2012): 35-42.

Lissowska, Maria. "Welfare against Growth Gains in Post-Transition Countries. What are the Consequences for Stability?" Economics: The Open-Access, Open-Assessment E-Journal 8, 2014-13 (2014): 1-37, http://dx.doi.org/10.5018/economics-ejournal. ja.2014-13.

Marzinotto, Benedicta. "The growth effects of EU cohesion policy: a meta-analysis." Bruegel Working Paper No.14 (2012).

Marcello, Estevão and Nargis Nigar. "Wage moderation in France." Working paper International Monetary Fund No. 02/151 (2012): 11-20.

Meager, Nigel and Stefan Speckesser. "Wages, productivity and employment: A review of theory and international data." Institute for Employment Studies, European Employment Observatory Thematic Report (2011): 52-60.

Mrak, Mojmir. "Global imbalances and global governance." Financial, Economic and Social Crisis, ed. Sony Kapoor et al. (Brussels: European Parliament, 2011): 40-50.

Onaran, Ozlem and Giorgos Galanis. "Is Aggregate Demand Wage-Led or Profit-Led?" International Labor Organization Working Papers No. 40 (2012), accessed September 6, 2015, http://www.ilo.org/wcmsp5/groups/public/---ed_protect/---protrav/---travail/ documents/publication/wcms_192121.pdf.

Onaran, Ozlem and Thomas Obst. "Wage led-growth in the EU15 Member States." Foundation for European Progressive Studies Working Paper (2015), accessed on March 10, 2016, http://www.feps-europe.eu/assets/19c9c5a8-e57b-4c6e-9fcd14cce163335f/wage-led-growth-study-onaran-obst-20052015compressed-1pdf.pdf.

Onaran, Ozlem. "Wage share, globalization, and crisis: The case of manufacturing industry in Korea, Mexico, and Turkey." International Review of Applied Economics 23 
(2) (2009): 113-134.

Podkaminer, Leon. "The euro area's secular stagnation and what can be done about it: A post-Keynesian perspective." Real-World Economics Review 70 (2015): 2-16.

Podkaminer, Leon. "Development Pattern of Central and Eastern European Countries (in the course of transition and following EU membership." The Vienna Institute for International Economic Studies Research Report No.388 (2013): 44-50.

Stockhammer, Engelbert. "Wage-led Growth." Kingston University working paper No.5 (2015): 3-7, accessed October 3, 2015, http://www.socialeurope.eu/wp-content/ uploads/2015/04/RE5-Stockhammer.pdf.

Stockhammer, Engelbert and Rafael Wildauer. "Debt-driven growth? Wealth, distribution and demand in OECD countries." Cambridge Journal of Economics (2015), doi: $10.1093 /$ cje/bev070.

Stockhammer, Engelbert. "Why have wage shares fallen? A panel analysis of the determinants of functional income distribution." International Labor Organization Working Paper Conditions of Work and Employment Series No. 35 (2013).

Stockhammer, Engelbert. "Peripheral Europe's Debt and German Wages. The Role of Wage Policy in the Euro Area." Research on money and finance 29 (2011): 10-25.

Stockhammer, Engelbert, Ozlem Onaran and Louis Ederer. "Functional income distribution and aggregate demand in the Euro area." Cambridge Journal of Economics 33 (1) (2009): 139-159.

Stockhammer, Engelbert and Özlem Onaran. "Accumulation, distribution and employment: a structural VAR approach to a Kaleckian macro model." Structural Change and Economic Dynamics 15 (2004): 421-447.

Storm, Servaas and C.W.M. Ro Naastepad. "Wage-led or Profit-led Supply: Wages, Productivity and Investment." International Labor Organization Working Papers 36 (2015).

Torbjorn, Becker., Daniel Daianu, Zsolt Darvas, Vladimir Gligorov, Michael Landesmann, Pavle Petrovic, Jean Pisani-Ferry, Dariusz Rosati, André Sapir, and B. Weder Di Mauro. Whither growth in central and eastern Europe Policy lessons for an integrated Europe. (Brussels: Bruegel economic think tank, 2010): 24-46. 
Tridico, Pasquale. "Financial Crisis and Global Imbalances: Its Labor Market Origins and the Aftermath." Cambridge Journal of Economics 36 (2012): 17-42. 